Article

\title{
Decentralised Local Governance and Poverty Reduction in Post-1991 Ethiopia: A Political Economy Study
}

\author{
Yeshtila Wondemeneh Bekele * and Darley Jose Kjosavik \\ Department of International Environment and Development Studies, Norwegian University of Life Sciences, Norway; \\ E-Mails: yeshitila.bekele@nmbu.no (Y.W.B.), darley.kjosavik@nmbu.no (D.J.K.) \\ * Corresponding author
}

Submitted: 5 February 2016 | Accepted: 20 June 2016 | Published: 18 October 2016

\begin{abstract}
After 1991, Ethiopia has introduced an ethnic federal governance system constituting nine regional states and two autonomous city administrations, Addis Ababa and Dire Dawa. The restructuring of the state seemingly led to the decentralisation of power to the regions and Woreda (district authority) levels local governance structure in 1995 and 2002 respectively. The purpose of this article is to examine the practices of decentralised local governance in Ethiopia in general and the local governance performance at the level of peasant association (Kebele) in particular. The article also analyses the link between the local governance and poverty based on three indicators: decentralisation and self-rule (DSR), local capacity for planning (LCP), and effectiveness of local governance system (ELGS). Data was collected from eight selected Kebeles of three different regional states through household survey, qualitative interviews and focus group discussions. The study shows that while the power and control of the central government is well established, the Kebeles lack the capacity and resources to deliver development. The LCP at Kebele level is weak because of organisational incapacity and institutional constraints related to DSR. The ELGS is also poor since Kebeles do not have any fiscal rights and administrative power for the reasons associated with DSR and LCP. The government has been implementing poverty reduction strategies using productive safety net programmes and farmer training centres. These, however, have not had the desired outcome due to organisational and institutional incapacitation of Kebele administrations.
\end{abstract}

\section{Keywords}

decentralised governance; FTC; Kebele; poverty reduction; PSNP

Issue

This article is part of a multidisciplinary issue of Politics and Governance, edited by Andrej J. Zwitter (University of Groningen, The Netherlands) and Amelia Hadfield (Canterbury Christ Church University, UK)

(C) 2016 by the authors; licensee Cogitatio (Lisbon, Portugal). This article is licensed under a Creative Commons Attribution 4.0 International License (CC BY).

\section{Introduction}

In 1991, The Ethiopian People's Revolutionary Democratic Front (EPRDF) established an ethnic federal governance system, which constitutes nine regional states and two autonomous city administrations (Addis Ababa, the capital of Ethiopia and Dire Dawa). Furthermore, the government implemented a third restructuring of the State in 1995 under the new Constitution, which is based on the principle of ethnic federalism that divides power between federal and ethnic-centred territorial Regional States (RS). As a result, power has been shared with the Regions that led to the emergence of a new power structure at the centre and peripheries. The decentralisation process was further extended to Woreda (district) in 2002 , based on the devolution of finance, human resources and political power from regions to the fourth tier of local governance structure at the Woreda level ${ }^{1}$.

\footnotetext{
${ }^{1}$ Woreda is an Amharic term that refers to the next administrative tier after the regional level of government (similar to a district in many other countries). It is managed by an elected council of members and a strong executive that is derived from the council.
} 
The purpose of this article is to examine the practices of decentralised local governance in Ethiopia in general and the local governance performance at selected Peasant Associations (PA) or Kebele, the lowest level local administration $^{2}$. It also elucidates the governance principles and practices based on primary empirical data gathered through household survey, interviews and focus group discussions. Primary data sources at the national level include Government Institutions' White Papers supplemented with key informant interviews.

The link between local governance and poverty is analysed based on indicators developed for the purpose, such as decentralisation and self-rule (DSR), local capacity for planning (LCP), and effectiveness of local governance system (ELGS). In order to attain this objective, the article addresses the following research questions: What are the emerging governing practices in post-1991? Is poverty being adequately addressed through decentralised local governance structures in post-1991 Ethiopia?

The following section (i.e. Section two), discusses the decentralised local governance framework of poverty analysis which is developed based on review of relevant literature. Section three explicates the methodology and study context. Section four discusses an emergent post1991 local governance practice in Ethiopia based on review of relevant literature and data from the field study. Section five presents the local governance system and institutional structure based on empirical data and relevant literature reviews. Section six analyses the decentralised local governance practice and poverty reduction experience at Kebele level administration. A brief conclusion, stitching together the main elements of the overall argument is delineated in section seven.

\section{Decentralised Local Governance: A Conceptual Framework}

Governance is an elusive term (Meuleman, 2008). In academia, there are controversies about governance as a concept. Some scholars consider governance as an ideological imposition against developing countries to reconstruct the state structure in accordance with neo-liberal orientation (Harrison, 2004). In fact, governance is different from government in the sense that government is the structure and function of public institutions, while governance is the way government gets its job done in cooperation with other stakeholders (Kettl, 2015). In other words, it implies a process.

The term governance denotes different meanings for different people. For some scholars, it refers to a mechanism of creating a newly ordered rule and collective action (Stoker, 1998). For others, it implies a new pattern of decision-making and platform for participation (Chhotray \& Stoker, 2009). For others, it still signifies a new technique and mode of governing practice (Dean, 2010;
Miller \& Rose, 2008). Some consider it as the totality of relations among actors in addressing societal problems (Meuleman, 2008).

Decentralized and strong local governance system is considered as a prerequisite for sustainable development and poverty reduction. Decentralised local governance is a system of decision-making or a framework for participatory resource and political management at a subnational level of administration (Ali Khan, 2013). It constitutes two major elements: decentralisation and local governance. Local governance is a set of institutions, actors, mechanisms and processes created by the constitution through which local people articulate their interest, negotiate their difference, exercise their right and make decisions (Shah, 2006). Whereas, decentralisation denotes the transfer of power from national to subnational structures of government, assigning resources to local authorities through de-concentration, delegation, or devolution. The decentralisation process constitutes four major interrelated components, namely political, administrative, fiscal and economic (Boko, 2002; Schneider, 2003).

Political decentralisation marks the transfer of political power to the subnational echelon of administration. The decentralisation of power gives autonomy to local authorities to make independent planning and decisions on important local matters (Schneider, 2003; Treisman, 2007). The fiscal decentralisation devolves resources to local authorities to carry out their activities, and coordinate and lead local economic development initiatives (Boko, 2002; Davoodi \& Zou, 1998; Schneider, 2003). Economic decentralisation expedites liberalisation of the economy by transferring public sector services to private or voluntary associations, allowing the market to take a leading role in resource generation and allocations. Moreover, most of the service provisions are privatised; a significant degree of deregulation under market (the private sector) system coordinates basic services including health, education, water, electricity and others (Schneider, 2003; Treisman, 2007). For the purpose of this article we combined and adopted perspectives illustrated by both Shah (2006) and Ali Khan (2013). We define decentralized local governance as the institution, or structures, which exercise self -rule right, participatory planning process and delivering capacity of social service at the local level to meet or satisfy the need of local people. This definition captures the indicators we developed in the framework of analysis in Figure 1.

In retrospect, in this framework of analysis, poverty reduction efforts at localities require Decentralization and self-rule right (DSR) rights. DSR consolidates Local Capacity for Planning (LCP), which is a pivotal instrument in local economic development and mobilisation of resources. The local actors in pursuit of their interests are motivated to take part in local governance processes in order to get access to and control over resources. The in-

\footnotetext{
2 Kebele is an Amharic word which means neighbourhood referring to the lowest grassroots administrative unit after the Woreda, recognized by both federal and regional constitutions as lower echelon of local administration in both urban and rural areas.
} 


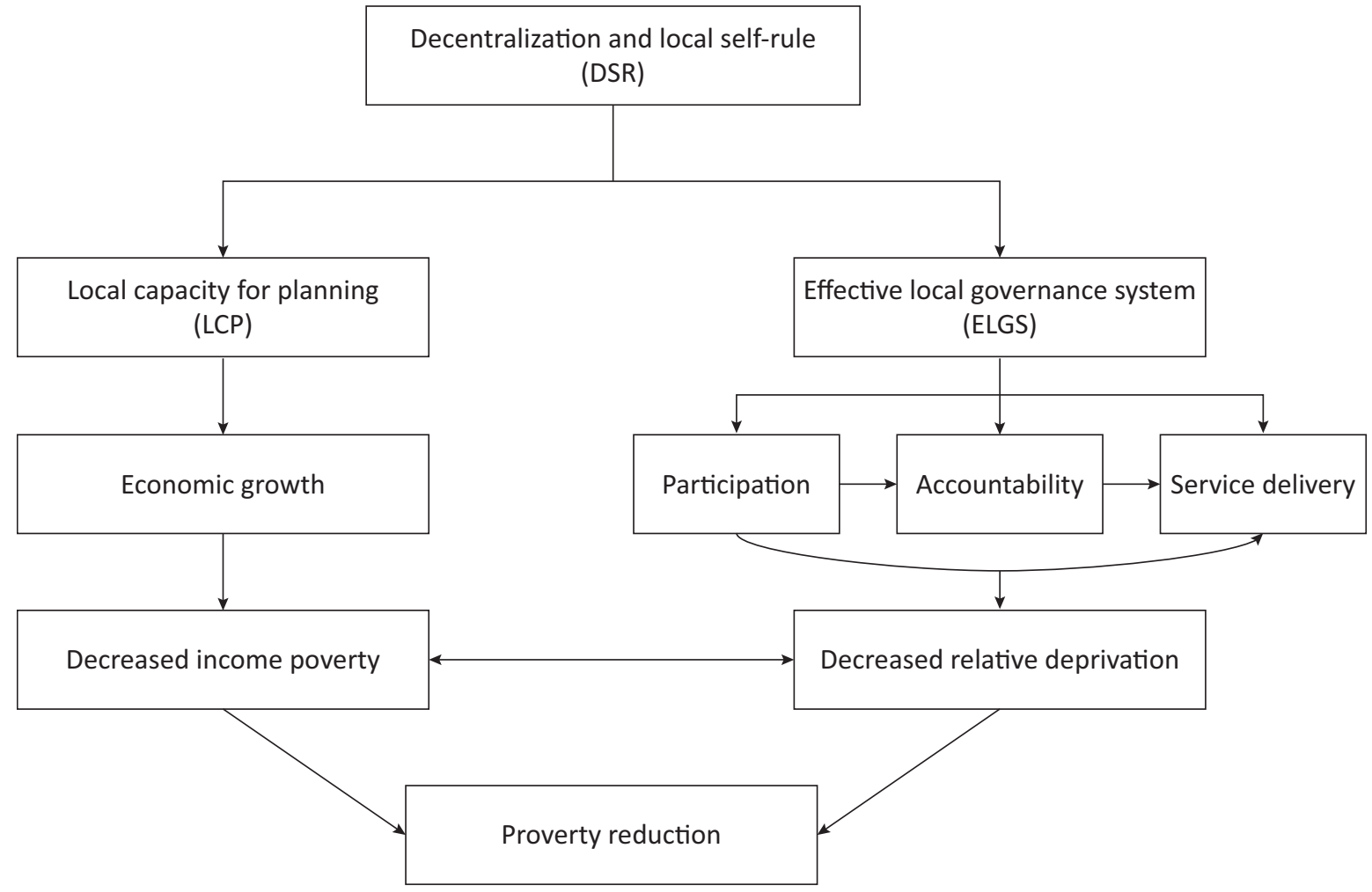

Figure 1. Framework for decentralised governance. Source: Adapted and modified from Ali Khan (2013).

teraction of these actors prompts local economic development, which is key in the reduction of income poverty at localities as illustrated in Figure 1.

In addition to LCP, as depicted in Figure 1, DSR is assigned the role of building an effective local governance system (ELGS), a vital instrument for addressing poverty-reduction, relative deprivation and social exclusion at localities. ELGS improves the service delivery capacity of local governance systems. Because the transfer of power, resources, and responsibilities encourages representation, accountability together with participation, inclusive development, and empowerment to make collective decisions based on local people's interest. It also motivates local entrepreneurial capacities in the provision of improved service delivery. However, decentralised governance is not always successful. At times it may result in unexpected indirect consequences, particularly in multi-ethnic societies. It is therefore, not heretic to propose that, if a dominant ethnic group controls financial, human resources, and political power, the subsequent struggle for resources may spark resource-based ethnic conflicts.

\section{Methodological Considerations}

A mixed methodology research approach is adopted, combining qualitative and quantitative methods. Purposive sampling was employed to select multi-layered study areas from region, zone, district, and Kebele; while, systematic random sampling method was used to frame sample size, select households and to draw their views from local areas. Data was collected from three purposefully selected regions, which represent different agroclimatic zones, livelihood patterns, ethnicity, and historical traditions. Gamo highlands represents the 'Enset' (false banana)-based livelihood, highland agro-climatic zone, minority ethnic group from southern Ethiopia. Jimma represents the cash crop-based livelihood, mid land agro-climatic zone, Muslim and majority Oromo ethnic groups. Deberberhan area represents grain cropbased livelihood, low and high land agro-climatic zones, and majority Amhara ethnic group. Accordingly, the quantitative data was collected from a total of 518 households in eight rural Kebeles.

For data collection, we used both structured and semi -structured questionnaires. Likert scale questions were used for the survey, and a series of interviews and focus group discussions were held with key informants of the study and local peasants. The respondents for the questionnaire survey were farmer households who were randomly chosen from the selected Kebeles. The key informants included Kebele administrators, development agents, peasants, and scholars who are informed of the setting. The socio-economic background of the respondents of the household survey are given in Table 1.

Table 1 depicts that the majority of respondents are male $(93.2 \%, N=483)$, and their main occupation (livelihood) is agriculture (92.5\%, $n=479)$. In terms of education, most of the respondents are primary school dropouts $(45.8 \%, n=237)$ and others are illiterate $(42.9 \%, N=222)$. About a third $(29.6 \%, n=154)$ of the households earn a monthly income below 300 
Table 1. Socio-economic background of respondents $(N=518)$. Source: Survey data $(2011 / 2012)$.

\begin{tabular}{llll}
\hline Background & Category & N & \% \\
\hline Occupation & Farmer & 479 & 92.5 \\
& Others & 39 & 7.5 \\
\hline Education & Illiterate & 222 & 42.9 \\
& Primary & 237 & 45.8 \\
& Secondary and above & 59 & 11.3 \\
\hline Gender & Male & 483 & 93.2 \\
& Female & 35 & 6.8 \\
\hline Household income (in ETB) & $<100$ ETB & 118 & 22.8 \\
& $101-300$ & 154 & 29.7 \\
& $301-500$ & 124 & 23.9 \\
& $>500$ ETB & 122 & 22.6 \\
\hline
\end{tabular}

Ethiopian Birr (USD 15.8). Nearly $80 \%$ of the respondents described their income as less than USD 30 (which is below the USD 1.25 per day poverty line).

\section{Post-1991 Local Governance Practice in Ethiopia}

The ethnic federal system that was established in post1991 Ethiopia constitutes nine regional states and two autonomous administrative cities. The decentralized power of the state is divided between the Federal and National Regional States in conformity with the 1995 Constitution. Each region has been awarded a quasi-sovereign status and self-rule authority, enshrined in separate autonomous Constitutions. Regions have also assumed the power and right to prepare their own socio-economic development plan, to mobilise resources and to allocate and utilise regional budgets. Both federal and regional constitutions have ensured authority for self-rule and share-rule at all levels of administration (Abbink, 1997; Fiseha, 2006).

Articles 50 and 51 of the 1995 Constitution enlist the powers and responsibilities of both Federal and Regional states. The decentralisation of power from centre to regions is carried out in terms of ethnic representations, ethnic geography and historical role of ethnic groups. The system developed is akin to neopatrimonialism but has a character of consensual democracy (Chanie, 2007; Mengisteab, 2008). The decentralisation has created a different locus of power in the regions by incorporating emerging ethno-elites. It has also introduced a kind of participatory and accommodative governance structure both in the region and at the centre (Fiseha, 2006). Apart from political and economic decentralisation, an emerging new governing practice of the post1991 period manifests multiculturalism, developmentalism, socio-cybernetics and statistical-based governance as major characteristics of governance.

Multiculturalism is the widely applied governance approach in the post-1991 period. It is used as a means of engendering legitimacy and constructing governable subjects under a plea for ethnic equalities. It is rationalised on the tenet of national operation and implies that the fundamental problem of the Ethiopian state emanates from 'unequal ethnic relations'. The rationale further asserts that political engineering under broader framework of 'Andet Ethiopia' (a unitary State or one Ethiopia), adhering to the Pan-Ethiopia project, did not succeed because of assimilation policy by previous governments. The core governance problem was articulated as a lack of political settlement and an inclusive governance structure to accommodate the competing interests of ethnic groups. Therefore, promotion of cultural pluralism in the new multiculturalist governance is seen as an indispensable means to avoid ethnic rifts and to emancipate the masses from abject poverty (Fiseha, 2006; Turton, 2006).

The ethnic federalism can be viewed as a pioneering effort similar to Haile Selassie's modernisation endeavour of the mid-1900s. Many scholars argue that the approach is not optimal. Nevertheless, it has brought significant dynamics to the political, economic and social settings of the country. Politically, revolutionary democracy and ethnic federalism have emerged as leading agencies; economically, a free market economy with a bigger role for the state has been introduced, and socially, cultural pluralism, with Amharic notion of 'BehereBehereseboch' that refers to nation and nationality, became a catchphrase of daily life and a powerful discursive narrative of political mobilisation.

Multiculturalism prompts the rise of ethno-elites in the regions with strong sentiments of ethnic identity ( $\mathrm{Ab}$ bink, 2009). The central government has crafted a controlling mechanism against these 'unruly' elites, based on the principle of democratic centralisation. However, the growing patronage practice has been posing a threat to democratic transition and consolidation. The ethnic politics prompts recruitment to political offices and access to jobs to be along ethnic lines. To this end, the rising ethno elites have organised a complex informal network both in their respective regions and national gov- 
ernment to control, survive and dominate the politics (Abbink, 2009; Chanie, 2007).

Developmentalism is another governing approach that has emerged since 2001 following the split in leadership of the Tigray People's Liberation Front (TPLF) and intensified by the election crisis of 2005. The government has apparently been articulating that achieving an accelerated development was indispensable for the survival of the nation (Gebresenbet, 2014). Consequently, it claims a dominantly leading role in both the economy and politics. It has been justifying the rationale to do so grounded on narratives of poverty reduction and sustainable development. The trend ushers in a new economic and political governance approach with the main objective of mainstreaming national politics. For example, the controversial large-scale agricultural investments which some scholars and rights groups identified as 'land grabbing' has been introduced (Lavers, 2012; Makki \& Geisler, 2011). The new large-scale agricultural investment projects dispossess properties, particularly land from smallholding farmers and the urban poor who are considered unproductive. Land is subsequently transferred to an emerging national private sector and international investors.

Access to land has given way for a new rising ethnoelite class. Hence, families and close allies of these rising ethno-elites have accumulated enormous wealth from a heavily regulated land market supervised and operated by Federal and Regional governments (Lavers, 2012; Makki \& Geisler, 2011; Pausewang, 2004). They have emerged as politically and economically powerful family elites with strong bases in the regions. The trend marks the new economic governance features that emerged from the reconfiguration of political structures and consolidation of ethno-elite powers.

Socio-cybernetics is another emerging governance instrument, widely applied in the post-1991 period. It refers to communication and controlling methods in the governing process that rely on information processing capacities (Pierre \& Peters, 2000). One of the remarkable features of this period is the massive capacity for steering, which is supported by the application of information and communications technology (ICT). The government has introduced and expanded ICT into districts and remote rural areas through the so-called WAN (wide area network) and various nets such as School-Net, WoredaNet, Agri-Net, HER-Net, Revenue-Net and Health-Net programmes (Lessa, Belachew, \& Anteneh, 2011).

The new ICT-driven governance has increased the penetration and information-gathering capacity of the state by penetrating into remote rural areas. The massive broadband internet connection installations, the expansion of community radio, improvement of telecommunication (free-call service, teleconferencing and other methods, particularly mobile phones) all over the country have, therefore, significantly improved the controlling and communication capacity of the state (Belachew, 2010).
Apart from ICT, the government has created a complex and sophisticated network of political control of all rural households, which is nicknamed 'one to five'. It has created a multiple but hierarchical layer of organisation that encompasses the various segments of the society including the youth and women. These networks comprise the popular wing, 'Hezibawi Kenefe', together with the government wing, 'Mengestawi Kenefe', and the political wing, 'Derjitawi Kenefe'. The Government has assigned each household to at least one of these organisational structures. It has also devised a mechanism to tie one to the other and to intertwine all of them together under one locus of control. These complex threads of organisations and networking give the government absolute social and political control over the respective localities (Snyder et al., 2014).

Likewise, the incorporation of peasants into a complex web of political control, one to five and other networking, is also used as a means of infusing ideology. The farmers have been ensnared by the reigning ideology of the government. The ideology is inculcated through a series of meetings, indoctrination and in public discussions. Peasants also receive formal ideological training through farmer training centres (FTCs). Therefore, the government is rather successful in turning peasants into subjects. In all study areas, the majority of farmers seemed to be strong supporters of the government and displayed a rather uniform character and thinking, regardless of geographic and other considerations. The operations of modern government, according to Miller and Rose (2008), advance through the accumulation and tabulation of facts about the governed subjects. Hence, the government employs organised statistical techniques to calculate tax returns, adopt social reforms and compute the gross national product, growth rates of different economies, rates of inflation and the money supply. From these calculations and tabulations emerge written reports, drawings, pictures, numbers, charts and graphs, for use as a means of governing citizens.

In post-1991 Ethiopia, the government has intensified the application of advanced statistical methods to analyse and depict the economic, social and political status of the country. It also consolidated and expanded the capacity of the Central Statistical Authority (CSA) - a government agency responsible for collecting and disseminating statistical data. This agency generates statistical data of various development indicators under the Ministry of Finance and Economic Development (MoFED). According to a scholar we interviewed, 'EPRDF employed statistical techniques to convince first single-digit and then double-digit economic growth and miracles of economic growth since the mid-2000s to the people at large and the international community, in particular's. The statistics-based governance applications have greatly helped the government to disclose its performance and engender legitimacy as developmental state. In the next section, we briefly discuss the evolu-

\footnotetext{
${ }^{3}$ Interview with a scholar in February 2012, Addis Ababa.
} 
tion of local governance institutions, the practice of decentralized local governance in post-1991 and the performance of selected local governance institutions based on three indicators (DSR, LCP and ELGS).

\section{Local Governance and Local Institutions in Post-1991 Ethiopia}

The local governance system constitutes integrated institutions of production and governance that surround and connect local communities. It incorporates different kinds of social, economic and political organizations and functions. Some notable examples of local level governance systems are community resource mobilization orders, social engagement and reciprocity instruments, security arrangements, asset management, conflict resolution mechanisms, infrastructure and sector services development apparatus (Bardhan, 1991; Saito, 2008). In Ethiopia's case, local governance is organised under Kebeles.

\subsection{The Local Governance Structure: A Historical Perspective}

Historically, the local administration institutions were evolved during the reign of Menlik II (1886-1913), as garrison towns known as 'Ketamas' or district towns. Because of the limited penetration capacity, the state could not establish local administration at all rural localities. It was operating from garrison towns. During the reign of Haile Selassie, the local governance restructuring was initiated under 1944 and 1966 proclamations, but could not establish administrative units in the local realm (Ayele, 2011; Zewde \& Pausewang, 2002). The state, using the district towns as a springboard, had been transferring investible surplus of product from the rural areas through tax, compulsory contribution and other mechanisms. No meaningful public investments were made in rural areas.

The 'Derg' or the military regime had established the grassroots local governance structures (Kebeles) under proclamations 31 and 71 of 1975 (Engdawork, 1995; Mammo, 1999). The role of the Kebeles was limited to land redistribution, local policing and coordinating social services. They were not given or allowed any mandate to plan and execute local development activities. In fact, the creation of the local administration structure had reduced routine local governance service provision.

Like its predecessor, the 'Derg' Government did not make significant public investments in the rural sector. Rather, it forced the rural people to become organised under cooperative groups, which were modelled after the former Soviet Union and imposed a compulsory grain quota delivery. The grain quota delivery system was aimed at ensuring sustainable and cheap supply of basic food commodities to the growing numbers of urban people, to quell any possible political opposition from the critical urban mass. The rural Kebeles have therefore been used as means for appropriating surplus product and transferring surplus to urban areas where the government sought to establish a political base (Abegaz, 2004; Pausewang, 2004). Eventually, political engineering brought neither economic development nor agrarian transformation to rural areas.

In sum, in post-1991 Ethiopia, the EPRDF has continued to use the Kebele as local structure without making any significant structural changes. The legal structure of the local governance was based on Article 39(3) and 50(4) of the 1995 Ethiopian Federal Democratic Republic (EFDR) constitution. The local authorities (Kebeles) have not been assigned any specific powers, except the Woreda or district authorities, which are authorised to initiate, plan and execute development activities. Hence, the power of the local authority is confined to the delivery of basic services as before (Assefe $\&$ Gebre-Egziabher, 2007; Ayele, 2011).

\subsection{The Local Governing System and Leadership}

The administration structure of the current Kebele institutions comprises of an elected council of 100 members known as 'Yemeto Shengo', an executive committee of five to seven members 'Kebele Cabinet', a social court known as 'Frede Shengo' and a local militia force which is known as 'Tataeki'. A diagrammatic representation of the institutional structure of Kebele is given in Figure 2 below.

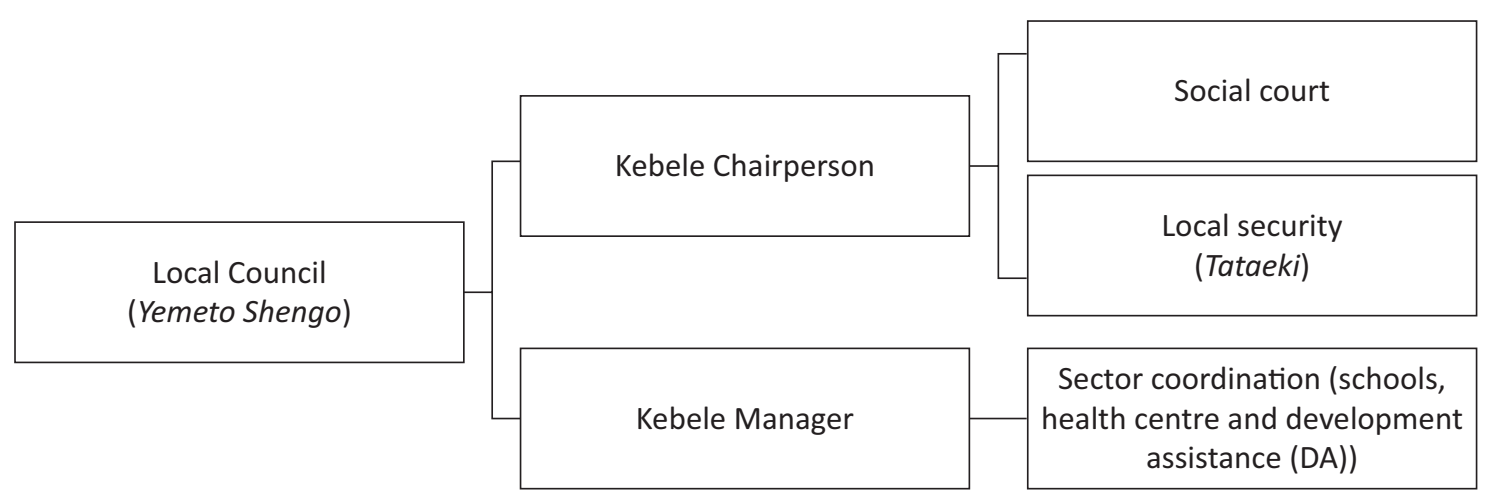

Figure 2. The institutional structure of Kebele. Source: Sketched by the authors based on the information from local authorities. 
The main responsibilities of the Kebele council and executive committee are endorsing the development plan, which is prepared by and directed from Woreda authorities, ensuring the collection of land and agricultural income tax, organising local labour and in-kind contributions to development initiatives, and mitigating local conflicts within the jurisdiction of local community social courts. Kebeles also steer the delivery of basic social services such as education and health in their respective localities in consultation with the Woreda and coordinators of the services at Kebele level such as school and health centre heads (Snyder et al., 2014).

Regarding local leadership, Kebele authorities are led by an executive body of five to seven cabinet members including chairman, three council members, a Kebele manager assigned by a Woreda, development agent, health extension officer and school director. The manager, who is reasonably educated, salaried and appointed by a Woreda, recently emerged as the most influential actor in the local affairs. In addition to the Kebele manager, development agents also play an important role in issues related to agricultural production and coordinating farmer training centres (FTCs) (Lefort, 2010).

\subsection{Decentralisation and Local Governance Performance in Post-1991 Ethiopia}

Decentralisation of power to sub-national administration is considered as an essential instrument for augmenting local economic development. It promotes empowerment to encourage different actors (state and non-state) to take part in coordinated development activities of localities (Bardhan \& Mookherjee, 2006; Saito, 2008). It also helps to enhance service delivery and inclusive development. According to Grindle (2007), decentralisation may not necessarily result in faster, inclusive and sustainable development. We identify three major indicators: DSR, LCP and ELGS as indicators to measure local governance performance at Kebele level.

\subsubsection{Decentralisation and Self-Rule (DSR)}

The EPRDF-led government has applied decentralisation as a key means of political settlement and engendering legitimacy. The decentralisation process was undertaken in two phases: to the regions in 1995 and to the Woredas in 2002 (Assefa \& Gebre-Egziabher, 2007). The decentralisation of power to the regions primarily gave selfgovernance right but has also substantially furthered the shared-rule right to fair and equitable representation in the federal state (Abbink, 1997; Turton, 2006).

The first phase of decentralisation was implemented between 1991 and 2001. It was aimed at creating and consolidating regional national government's capacity for self-rule and was designated as mid-level decentralisation. The legality of the decentralisation process was stipulated in the transitional charter (1991) and the Fed- eral Constitution (1995). In this phase of decentralisation, political, fiscal and administrative powers were transferred to the regional states. National regional governments have been entrusted with all legislative, executive and judicial powers in respect of all matters within their jurisdiction, except those that fell under the federalstate domain such as defence, foreign affairs, and economic policy (Assefe \& Gebre-Egziabher, 2007).

The second phase of decentralisation, involving district level decentralisation programmes (DLDP) and urban management programmes, took place in 2002. This phase resulted in the restructuring of institutions at Woreda level administrations, together with devolution of political and fiscal power from regions to Woredas. DLDP devolved a considerable portion of human and financial resources in the form of a block grant to Woreda by rolling down power and resources from zones (the third tier of administration above Woreda) to Woreda level. The Woredas were also given autonomous right to plan and implement development activities within the bounds of resources available to them (Snyder et al., 2014).

Rural Kebeles have not experienced any significant change in its nature nor in its structural dimension. Though the government claims that implementing agriculture-led industrialisation will place the rural people at the centre of the policy locus, there is no elaborate institutional framework, which is capable of transforming the fragmented smallholding agriculture and the subsistence livelihood of the rural people at grassroots level. The decentralisation process floated in the regional and to some extent at Woreda levels. As one local official of the rural Kebele of Jimma area noted:

"We have neither full power to make decision on our local matters nor resources to stimulate local based development activities. We simply wait for order from Woreda officials. If the government devolves the full power to make decisions based on our people's interest and even to collect or develop limited resources in order to speed up local development, we can make a big difference. Lack of power has really constrained us not to fully commit to community development. Take a watershed management programme. It is a good example. It is quite essential for local people but most local people are against it. They do not feel a sense of ownership."4

As noted by this local official, Kebeles have neither fiscal power with relevant resources nor are they allowed to generate local finances. The mandates of tax and other collections are given to the Woreda authorities. The Kebele officials are not allowed to engage in any financerelated matters (Yilmaz \& Venugopal, 2008). This has implications for the effective functioning of the local institutions. The powerlessness of Kebele was reinforced in the view of local farmers in the Azo and Dorze areas of the Gamo highlands. They preferred the manager to the

\footnotetext{
${ }^{4}$ Interview with local official in February 2013, Jimma area.
} 
Kebele chair. As one farmer in Azo Gule noted:

"The Kebele leaders do not have the real power to make decisions. The political power is vested on the Woreda leaders. Therefore, they are simply carrying out orders given from the Woreda. The Woreda propose, develop and simply request the local people to approve their decision. What we do is simply approving their decision through the council and Kebele administration." ${ }^{5}$

During the household survey, the respondents were asked about their opinion on decentralised governance. Table 2 presents the findings of the household survey about decentralisation of power and resources at Kebele level.

As depicted in Table 2 below, regarding decentralisation and local self-rule in the respective local communities, the respondent view indicates that $19.3 \%(N=100)$ disagreed and $36.7(N=190)$ were undecided about the questions. The mean value is 3.03 . The majority of the local people seem not to agree with decentralisation of power and self-rule practices in their local arena. The result of the survey is also consistent with what we observed in the field. The Kebeles lack substantive power and they are under the shadow of the district (Woreda) administrations. They do not exercise autonomous political, fiscal and administrative responsibilities, although they do exercise limited administrative prerogatives. They are, nevertheless, under strict Woreda dominance.

\subsubsection{Local Capacity for Planning (LCP)}

LCP is one of the major aspects of decentralised local governance processes. It refers to the institutional and policy capacity of local actors in performing their respective responsibilities. The policy capacity refers to the ability of local actors to contextualise the policy direction and allocate scarce resources to implement policy (Painter \& Pierre, 2005). Local institutional capacity denotes specified rules, procedures, and norms that govern interactions of local institutions by delineating their role and responsibilities with adequate conflict mitigation mechanisms (Peters \& Pierre, 1998). Hope (2008, p. 152) de- scribes institutional capacity as 'the competency of individuals, public sector institutions, private sector entities, civil society organisations, and local communities to engage in activities in a sustainable manner that permit the achievement of beneficial goals'.

LCP gives local people the opportunity to develop a feasible development plan responding to the prevailing local social problems and available resources. It enhances local people's capacity to efficiently utilise available resources by prioritising their pressing social problems according to the available resources. Moreover, it helps to synergise the local plan with national, indigenous knowledge, cultural context and agro-ecology settings of the society. Furthermore, it also gave a sense of ownership and an opportunity to the local people to decide on their own matters (Saito, 2008).

Articles 39(3) and 50(4) of the Federal and Regional Constitutions of Ethiopia confer power on local authorities to make a local development plan and coordinate development initiatives. Although the power to prepare development plan is given to the Kebele authorities, they do not fully exercise this power. In fact, they provide input for an annual development plan which is prepared by Woreda authorities (Snyder et al., 2014). This trend affects the LCP and institutional capacity of the local authorities to coordinate development efforts. Table 3 presents the household survey results concerning local capacity for planning in selected Kebeles. A farmer in Goshe Bado Deberberhan area stated:

"Comparing to the Derg regime, the current Kebele administration is better. The chairperson and other committee members were more accessible to the local people. They listen to the people. However, they had had a big problem regarding planning and coordinating activities. The problem is attributed to skill gap and lack of power. They do not have sufficient capacity so that the Woreda officials did the planning task. Go and ask our officials who has prepared this year local plan? They would tell you the Woreda did that." 6

The farmer's remark echoed in a similar conversation with local officials. Snyder and others who researched on local planning practice (see Snyder et al., 2014) found that Kebeles were involved in the initial planning process

\footnotetext{
${ }^{5}$ Interview with local farmer in Azo Gule in January 2012, Gamo highland.

${ }^{6}$ Interview with local farmer in Goshebado in December 2013.
}

Table 2. Response to the statement 'local governance is decentralised and all-inclusive'. Source: Survey data (2011/2012).

\begin{tabular}{|c|c|c|c|c|c|c|c|c|c|}
\hline \multirow[t]{2}{*}{ Indicators } & \multirow[b]{2}{*}{ Mean } & \multirow[b]{2}{*}{ SD } & \multicolumn{7}{|c|}{ Household ratings (\%) } \\
\hline & & & $D K$ & $S D$ & $D A$ & $U D$ & $A G$ & $S A$ & Total \\
\hline $\begin{array}{l}\text { Local authorities are } \\
\text { decentralised and } \\
\text { all inclusive }\end{array}$ & 3.03 & 1.17 & $30(5.8)$ & 10(1.9) & $100(19.3)$ & $190(36.7)$ & $152(29.3)$ & $36(6.9)$ & $518(100)$ \\
\hline
\end{tabular}

Notes: $\mathrm{DK}=$ don't know, $\mathrm{SD}=$ strongly disagree, $\mathrm{DA}=$ Disagree, $\mathrm{UD}=$ Undecided, $\mathrm{AG}$ = Agree, and SA = Strongly Agree; figures in parentheses are percentages. 
(giving input) but Woreda authorities made the final decision regarding the plan. The respondents' views regarding Kebele's capacity to make and implement local plans are presented in Table 3.

Table 3 reveals that the majority of respondents (around $32.4 \%, N=168$ ) were undecided and a significant number of respondents $(32.2 \%, N=167)$ do not believe in local authorities independent capacity to plan and implement. Poor organisational capacity in terms of physical facilities, human and financial resources were also observed during field visits. Although the population and territorial size of the Kebeles have been changed; neither new institutional innovations nor improved organisational structures have developed to accommodate the dynamism. Hence, the Kebeles' local capacity to make plans remains limited. The findings of the survey also confirm this fact.

\subsubsection{Effective Local Governance System (ELGS)}

An ELGS comprises local institutional capacity for service delivery, accountability and responsiveness of local authorities, and participation and inclusion of the local people in the local governance system. All these dimensions of ELGS indicate the level and scope of local governance effectiveness and efficiency under decentralised governance notions. Effective service delivery to the poor is an integral aspect of poverty reduction efforts (Bonfiglioli, 2003; Grindle, 2007). The basic social services allow poor people to be productive members of the society. Therefore, the provision of services including education, health, family planning, road, electricity, water, agricultural support and security are essential in poverty reduction effort.

Ideally, accountability and responsiveness allow the local people to call officials and to hold them accountable to their performance. It is also an effective means to control corruption and embezzlement of meagre resources at localities (Rao \& Berg, 2005). Participation and empowerment in the local governance practice is another major aspect of local governance effectiveness (Bonfiglioli, 2003). As Alsop (2004) and Green (2012) note, poverty, power and right are inexorably interconnected. According to Alsop (2004, p. 4), political empow-

${ }^{7}$ Focus group discussion in February 2013, Dawa, Jimma area. erment that marks 'increasing the capacity of individuals and groups to make choices and to transform these choices into desired actions and outcomes' has had a significant impact on transforming the dependent poor into productive citizens.

Though the rural Kebeles represent the wider and larger segment of the society ( $83 \%$ of the Ethiopian population), they exercise very limited administrative power which is delegated by Woreda authorities. Their accountability is upward and not to the local people (Ayele, 2011). Their ability to deliver adequate and fast local services is severely constrained by resource problems. As one farmer noted in focus group discussion in Dawa, Jimma area: "The Kebele authorities try to give us a swift response to most of our questions at their best. However, because of resource problems, we were not getting adequate services" 7 .

As we witnessed in the fieldwork, most of Kebele administration runs with a shortage of resources. They did not even have a well-organised archive and record system, let alone necessary services. It is very difficult to get basic information about the Kebele.

Regarding participation, the current Kebele structures were much appreciated by local people in most of the study areas. Most of the farmers interviewed were involved in Kebele activities in one way or another.

Table 4 presents the views of local people from the study areas about local governance effectiveness in their respective localities.

The first statement addressed local service delivery. As we can see from the result, the overwhelming majority of respondents (mean value 3.46 , supposing 4 amounted to agreement) were not satisfied and 38.6 per cent $(N=200)$ agreed with statement, $12 \%(N=62)$ strongly agreed and $33.8 \%(N=177)$ were 'undecided'. The second statement was 'the local governance system is all-inclusive and participatory'. The overall mean value obtained from the respondents on this was 3.45. This means most of the respondents seemed to agree that the existing local system is participatory and all-inclusive. Accordingly, $42.9 \%(N=222)$ and $10.2 \%(N=52)$ of the respondents 'agreed' and 'strongly agreed' with the statement respectively. The third statement was about accountability of local authority to local people. Again,

Table 3. Response to the statement 'local authority has the capacity to make and implement local plan'. Source: Survey data (2011/2012).

\begin{tabular}{|c|c|c|c|c|c|c|c|c|c|}
\hline \multirow[t]{2}{*}{ Indicators } & \multirow[b]{2}{*}{ Mean } & \multirow[b]{2}{*}{ SD } & \multicolumn{7}{|c|}{ Household ratings (\%) } \\
\hline & & & $D K$ & $S D$ & $D A$ & $U D$ & $A G$ & $S A$ & Total \\
\hline $\begin{array}{l}\text { Local authorities have } \\
\text { independent capacity to } \\
\text { make local development } \\
\text { plan and implement them }\end{array}$ & 2.97 & 1.02 & $3(0.6)$ & $18(3.5)$ & $168(32.4)$ & $167(32.2)$ & $125(24.1)$ & $37(7.1)$ & $518(100)$ \\
\hline
\end{tabular}

Notes: $\mathrm{DK}=$ don't know, $\mathrm{SD}$ = strongly disagree, $\mathrm{DA}=$ Disagree, UD = Undecided, AG = Agree, and SA = Strongly Agree; figures in parentheses are percentages. 
Table 4. Response to the statements regarding local government effectiveness (service delivery, accountability, participation). Source: Survey data (2011/2012).

\begin{tabular}{|c|c|c|c|c|c|c|c|c|c|}
\hline \multirow[t]{2}{*}{ Indicators } & \multirow[b]{2}{*}{ Mean } & \multirow[b]{2}{*}{ SD } & \multicolumn{7}{|c|}{ Household ratings (\%) } \\
\hline & & & $D K$ & $S D$ & $D A$ & $U D$ & $A G$ & $S A$ & Total \\
\hline $\begin{array}{l}\text { Local service delivery } \\
\text { is not adequate }\end{array}$ & 3.46 & 0.93 & $2(0.2)$ & $3(0.6)$ & $76(14.5)$ & $177(33.8)$ & $200(38.6)$ & $62(12)$ & $518(100)$ \\
\hline $\begin{array}{l}\text { The local governance is } \\
\text { inclusive and participatory }\end{array}$ & 3.45 & 0.97 & $9(1.7)$ & $6(1.2)$ & $55(10.6)$ & 174(33.6) & $222(42.9)$ & $52(10)$ & $518(100)$ \\
\hline $\begin{array}{l}\text { Local authorities are } \\
\text { accountable to } \\
\text { the local people }\end{array}$ & 3.83 & 0.86 & 0 & $3(0.6)$ & $22(4.2)$ & $158(30.5)$ & $213(41.1)$ & $122(23.6)$ & $518(100)$ \\
\hline
\end{tabular}

Notes: DK= don't know, SD = strongly disagree, DA = Disagree, UD = Undecided, AG = Agree, and SA = Strongly Agree; figures in parentheses are percentages.

as evident in the results, the overwhelming majority of respondents believed that local officials are accountable to the local people. The mean value is 3.83 (almost agreement) and $41.1 \%(N=213)$ and $23.6 \%(N=122)$ 'agreed' and 'strongly agreed' to the question respectively. However, as we witnessed in the field work and evidences gathered during key informant interviews, the accountability of the Kebele authorities is upward to the Woreda level administration.

\section{The Practice of Decentralised Governance and Poverty Reduction at Kebele Localities}

Participatory decentralised local governance is generally better informed about the needs and preference of local community than central government, which has limited opportunities to access the reality from a distance. In decentralised governance, monitoring and controlling of local agents is easier (Bonfiglioli, 2003). Local people hold the elected officials accountable, and poor people get the opportunity to voice their interest in the political decision-making process. Moreover, the devolution of power gives more responsibility, ownership and incentives to the local people (Green, 2012; Saito, 2008).

The effectiveness of decentralised governance depends on the institutional capacity of local authorities and policy implementation capacity (poverty reduction strategies) by the state. Likewise, poverty needs to be addressed through effective policy instruments that are supported by workable institutions at all level of administration (Treisman, 2007). Institutional capacity has several dimensions such as human capital, infrastructure (physical capital) and capacity to deliver services. Institutional capacity is critical in implementing decentralised governance. Poor quality of institutions may cause resource embezzlement, delay or denial of service delivery to the local people, and in the worst case, sluggish local economic performance. Institutions, therefore, are quite essential to fight against poverty (Painter \& Pierre, 2005; Treisman, 2007).

The policy capacity (for developing poverty reduction strategies) is another major factor in decentralised governance. It guides the process of decentralised governance towards mitigating poverty challenges. As decentralised governance transfers power and resources to lower echelons of administration, it allows participation, fair resource distribution, empowerment and responsiveness. Decentralised governance thus creates a conducive ground for policy implementation (Painter \& Pierre, 2005).

As we noted earlier, the decentralisation of power to local governance institutions drifted at Woreda level administration. Although the majority of the people live in rural localities, decentralisation of power and devolution of resources has not extended to the grassroots administration (Zewde \& Pausewang, 2002). The poverty reduction efforts coordinated from Woredas have been implemented through three major approaches, namely enhancing agricultural productivity through improved technology, developing resilience to vulnerability and food insecurity through a Productive Safety Net Programme (PSNP) which aims to build assets and livelihoods of vulnerable households, and resettling farmers from drought-prone areas into fertile but less inhabitable locations in selected lowland areas of the country. For example, Woreda Agriculture and Rural Development Bureau (WORAD) coordinates the PSNP. The main responsibility of governing the PSNP is vested in specifically established Woreda Food Security Task Forces (WFSTFs). Figure 3 below describes the implementation of the PSNP at Kebele level administration. The Woreda task force coordinated by WORAD consists of WFSTFs, the Woreda Food Security Desk (WFSD) and the Woreda Office of Finance and Economic Development (WOFED).

At the Kebele level, the FSTF comprises of the selected council members, the chair of the Kebele, development agents and the Kebele manager. The role of the Kebele in the implementation of PSNP is limited to the selection of eligible households to the programme, collecting complaints from the beneficiaries and organising public meetings for the Woreda officials. Woreda, however, carries out the overall programme. Even the decision whether the household is to remain part of the programme or not is made by Woreda. Figure 3 presents the governing process of PSNP. 


\section{WoredaFSTF}

- Resolve any major problems or issues arising out of the selection process.

- Undertake spot checks on Kebeles

- Submit the list of participants to the Woreda Council for final approval.

- Review, compile and approve Kebele participant lists

- Compare planning figures from the region to the actual requested number of participants from the Kebeles, and take appropriate action.

- Propose allocation of participant numbers for each PA or Kebele.

- Set local criteria for beneficiary selection.
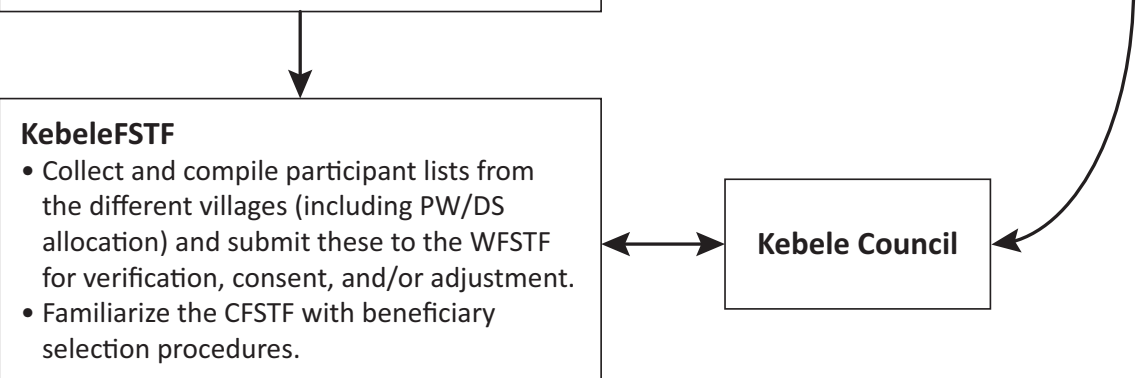
selection procedures.

Household/Community

Figure 3. PSNP governance framework at Kebele level. Source: Sketched by the authors.

Taking this figure into consideration, the role of the Kebele in poverty reduction is trivial. Most of the Kebele administrations could not provide accurate information about the magnitude and depth of poverty in their localities. They do not have information systems about basic data on demography or economic matters (such as land size, productivity, income, non-farm income, type of crop production), agro-ecology, vulnerability, types and level of technology, social service provision, or rural infrastructure coverage (electricity, road, telephone, water). In the areas where this research was conducted-Azo Gule, Chano Mile, Amaraena Bodo, Gerema, Merewa, Alyu Amba, and Goshe Bado-the researchers witnessed this fact. However, it should be noted that Alyu Amba, Chano Mile and Goshe Bado were relatively in a better condition compared to others as they did store some basic information about the area.

Another poverty mitigation mechanism at Kebele level is FTC. The FTC is considered a cornerstone to support small-scale agriculture in rural Ethiopia, and was introduced in 2002 in each rural Kebele. Three development agents are assigned to each FTC. They are trained in crop science, livestock, and natural resource man- agement. There are nearly 8,500 such centres throughout the country. The government's plan is to establish about 15,000 centres in the near future. About seven to ten committee members including development agents and selected model farmers manage the centre. The Kebele Chairperson is in charge of coordinating the FTC. The Committee's responsibility includes planning, examining the training and demonstration activities offered by the FTC. It also organises and maintains a demonstration field. The FTC provides training and technical assistance in the application of improved technology, production systems, market-orientated information, seed and seedlings of new crops, vegetables, fruit and forage varieties. FTC is part of the initiative to modernise and improve the agricultural system production in each Kebele.

FTC and PSNP are the two institutional (infrastructural) settings to address poverty at Kebele level. FTC aims to reduce poverty through intensification and diversification of agricultural products. It also provides assistance on market-related information and non-farm work opportunities to diversify the income of the farmers. The PSNP is the social protection programme for ensuring food security for vulnerable and food-insecure 
poor households through direct assistance (cash or food) and food-for-work arrangements. The implementation of both modalities have been limited by lack of fiscal and political power in Kebele administration.

The role of the Kebele in the PSNP is to identify and select beneficiaries for the Woreda authorities. Kebeles did not assume power and necessary resources to implement both PSNP and FTC initiatives because the government has not been providing substantial public investment in rural Kebeles. It seems to adhere to the same policy as the Derg governments. Therefore, lack of incremental rural public investment has remained the major challenge in tackling rural poverty. The resource transfers from rural areas to the centre have consolidated the power structure of the state, but prevent trickle-down to the poor, reinforcing dependency and systematically perpetuating poverty.

Some scholars criticise the poverty reduction scheme as top-down in that it conceives of the poor as subjects ultimately dependent on the state for their well-being. This understanding of the poor as subject involves a policy implication and consequence. Rather than ensuring the well-being of citizens, the government seems to be concerned with guaranteeing its own survival by amassing support from the poor subjects. Poverty reduction efforts are political in that poor households are allowed support on condition that they fully support the regime. For instance, in the case of the PSNP, poor households are identified and selected by WFSTF at Kebeles chaired by the Kebele chairperson. In most cases, the Kebele authority handpicks farmers who are loyal to the regime as a reward.

In our study, we also asked the peasants whether the PSNP was politically tied. The following tables present the results.

Tables 5 and 6 portray that majority of the respondents tend to believe that the PSNP is tied to political mo- tives. A total of $24.7 \%(N=128)$ of the respondents were 'undecided' on the issue while $28.1 \%(N=149)$ and $7.5 \%$ $(N=39)$ of respondents 'agreed' and 'strongly agreed' respectively. Majority of the respondents in Dawa $37.7 \%$, $N=26 ; 31 \%, N=22$ ) agreed and strongly agreed respectively and in Azo Gule Kebele $(52.9 \%, N=37 ; 14.3 \%$, $N=10$ ) 'agreed', and 'strongly agreed', respectively that the PSNP is tied to political motives.

The goal of the state, therefore, appears to be consolidating its control over the society rather than reducing poverty. Consequently, poor people get less consideration for empowerment and participation. Moreover, the practice maintains a dependency syndrome on aid among a wide spectrum of rural people who believe they are eligible for aid in response to their loyalty and support of the government (Dercon, Gilligan, Hoddinott, \& Woldehanna, 2009).

\section{Conclusion}

In post-1991 Ethiopia, an ethnic federal governance system was established, comprising Regional Governments and a Federal State, apportioning the state power between the two according to the 1995 Constitution, which is based on ethnic geography and identity. Each Region has been accorded a quasi-sovereign status and has awarded a self-rule right with the autonomy to have separate regional constitutions. In addition to an ethnic federal governance system, the state introduced decentralisation of power to local governance structure in 2002. Accordingly, the Woreda level of administration gave some political, fiscal, and administrative power to the Woreda authorities. They also assumed a mandate to plan and coordinate development activities at Kebele and Woreda administration level. However, Kebeles, as the lower echelon of local administration, have not experienced any significant change.

Table 5. Response to the statement whether PSNP is a political tool of Government. Source: Survey data (2011/2012).

\begin{tabular}{lllllllllll}
\hline Indicators & & \multicolumn{8}{c}{ Household ratings (\%) } \\
\cline { 3 - 11 } & Mean & SD & $D K$ & $S D$ & $D A$ & $U D$ & $A G$ & $S A$ & Total \\
\hline The PSNP is politically tied & 2.81 & 1.36 & $49(9.5)$ & $25(4.8)$ & $128(24.7)$ & $128(24.7)$ & $149(28.1)$ & $39(7.5)$ & $518(100)$ \\
\hline
\end{tabular}

Notes: $\mathrm{DK}=$ don't know, $\mathrm{SD}=$ strongly disagree, $\mathrm{DA}=$ Disagree, UD = Undecided, AG = Agree, and SA = Strongly Agree; figures in parentheses are percentages.

Table 6. Respondents' view about PSNP connection to political motives based on beneficiary Kebeles. Source: Survey data (2011/2012).

\begin{tabular}{|c|c|c|c|c|c|c|c|c|c|}
\hline \multirow[t]{2}{*}{ Indicators } & & & \multicolumn{6}{|c|}{ The PSNP is tied to political agenda } & \multirow[b]{2}{*}{ Total } \\
\hline & & & $D K$ & $S D$ & $D A$ & $U D$ & $A G$ & $S A$ & \\
\hline \multirow[t]{3}{*}{ Kebele } & Dawa & $\%(N)$ & $0(0)$ & $5.8(4)$ & $10.1(7)$ & $14.5(10)$ & $37.7(26)$ & $31.9(22)$ & $100 \%(69)$ \\
\hline & Azo Gule & $\%(N)$ & $0(0)$ & $0(0)$ & $0(0)$ & $32.9(23)$ & $52.9(37)$ & $14.3(10)$ & $100(70)$ \\
\hline & AlyuAmbaZuria & $\%(N)$ & $0(0)$ & $13.9(10)$ & $52.8(38)$ & $29.2(21)$ & $4.2(3)$ & $0(0)$ & $100(72)$ \\
\hline
\end{tabular}

Notes: $\mathrm{DK}=$ don't know, SD = strongly disagree, DA = Disagree, UD = Undecided, AG = Agree, and SA = Strongly Agree; figures in parentheses are percentages. 
The skills, knowledge and experiences of the Kebele administrations are inadequate in terms of organisational and institutional capacities, nor are they entitled to exercising any significant political, fiscal and administrative power. They simply serve as agents of district authorities. They are neither budgeted nor allowed to generate any local finances. Their role in local development activities and poverty reduction, therefore, is limited institutionally. In this study, three indicators were used to examine the role of Kebeles in local development activities, delivery of services to the local people and poverty reduction efforts. Based on the indicators DSR, LCP and ELGS as elucidated in this study, the role and performance of the Kebeles seem to be unsatisfactory.

DSR was not implemented at the Kebele level, and the findings indicate that the Kebeles lack the capacity and resources to deliver development. A system of upward accountability of the local officials to Woreda was established rather than downwards to the local people. The LCP is weak at Kebele level because of weak organisational capacity and institutional constraints related to DSR. The ELGS is poor since Kebeles did not assume any fiscal right and administrative power for the reasons associated with DSR and LCP.

The government enacted three major policy strategies to address rural poverty. These are: a) enhancing agricultural productivity through improved technology, b) developing resilience to vulnerability and food insecurity through PSNPs, which aim to build assets and c) improve livelihoods of vulnerable households, and resettlement of farmers from drought-prone areas to fertile but less inhabitable locations in selected lowland areas of the country. However, all these efforts are coordinated and managed by the Woreda administration. For example, two major poverty alleviation programmes operate at Kebele level, these being the PSNP and FTC. The first programme aims to support food-insecure and vulnerable households and the second is intended to increase the productivity of local households through the application of improved inputs for agricultural production via training and field demonstrations. However, as noted in this article, neither programme is fully functional because of lack of resources and power. Therefore, the absence of effective decentralised governance practice at local level in fact gravely constrains the performance of poverty reduction efforts and curtail local development initiatives.

\section{Conflict of Interests}

The authors declare no conflict of interests.

\section{References}

Abbink, J. (1997). Ethnicity and constitutionalism in contemporary Ethiopia. Journal of African Law, 41(2), 159-174. doi:10.1017/S0021855300009372

Abbink, J. (2009). The Ethiopian Second Republic and the fragile "social contract". Africa Spectrum, 44(2), 3-28.

Abegaz, B. (2004). Escaping Ethiopia's poverty trap: The case for a second agrarian reform. The Journal of Modern African Studies, 42(3), 313-342. doi:10. 1017/S0022278X04000217

Ali Khan, S. (2013). Decentralization and poverty reduction: A theoretical framework for exploring the linkages. International Review of Public Administration, 18(2), 145-172. doi:10.1080/12294659.2013. 10805256

Alsop, R. (2004). Power, rights and poverty reduction. In R. Alsop, (Ed.), Power, rights and poverty: Concepts and connections. Washington DC: World Bank.

Assefe, T., \& Gebre-Egziabher, T. (2007). Decentralization in Ethiopia. Addis Ababa: Forum for Social Studies.

Ayele, Z. (2011). Local government in Ethiopia: Still an apparatus of control? Law, Democracy \& Development, 15(1). doi:10.4314/ldd.v15i1.7

Bardhan, P. (1991). The economic theory of agrarian institutions. Oxford University Press.

Bardhan, P. K., \& Mookherjee, D. (2006). Decentralization and local governance in developing countries: $A$ comparative perspective (Vol. 1). Massachusetts: The MIT Press.

Belachew, M. (2010). E-government initiatives in Ethiopia. Paper presented at the 4th International Conference on Theory and Practice of Electronic Governance, Beijing, China. doi:10.1145/1930321.193033

Boko, S. H. (2002). Decentralization and reform in Africa. New York: Springer Science \& Business Media. doi:10.1007/978-1-4615-1111-3

Bonfiglioli, A. M. (2003). Empowering the poor: Local governance for poverty reduction. New York: United Nations Publications.

Chanie, P. (2007). Clientelism and Ethiopia's post-1991 decentralisation. The Journal of Modern African Studies, 45(3), 355-384. doi:10.1017/S0022278X07002662

Davoodi, H., \& Zou, H. (1998). Fiscal decentralization and economic growth: A cross-country study. Journal of Urban Economics, 43(2), 244-257. doi:10.1006/ juec.1997.2042

Dean, M. (2010). Governmentality: Power and rule in modern society ( 2 nd ed.). London: Sage.

Dercon, S., Gilligan, D. O., Hoddinott, J., \& Woldehanna, T. (2009). The impact of agricultural extension and roads on poverty and consumption growth in fifteen Ethiopian villages. American Journal of Agricultural Economics, 91(4), 1007-1021. doi:10.1111/j.14678276.2009.01325.x

Engdawork, D. (1995). Agricultural producer cooperatives: Some lessons of experience from Ethiopia. GeoJournal, 36(4), 353-360. doi:10.1007/BF00807950

Fiseha, A. (2006). Federalism and the accommodation of diversity in Ethiopia: A comparative study. Oisterwijk: Wolf Legal.

Gebresenbet, F. (2014). Securitisation of development in Ethiopia: The discourse and politics of developmen- 
talism. Review of African Political Economy, 41(sup1), S64-S74. doi:10.1080/03056244.2014.976191

Green, D. (2012). From poverty to power: How active citizens and effective states can change the world. Warwickshire: Practical Action Publishing.

Grindle, M. S. (2007). Going local: Decentralization, democratization, and the promise of good governance. Princeton: Princeton University Press.

Harrison, G. (2004). The World Bank and Africa: The construction of governance states. London: Routledge.

Hope, K. R. (2008). Poverty, livelihoods, and governance in Africa: Fulfilling the development promise. New York: Palgrave Macmillan.

Kettl, D. F. (2015). The transformation of governance: Public administration for the twenty-first century. Baltimore: John Hopkins University Press.

Lavers, T. (2012). 'Land grab'as development strategy? The political economy of agricultural investment in Ethiopia. The Journal of Peasant Studies, 39(1), 105132. doi:10.1080/03066150.2011.652091

Lefort, R. (2010). Powers-mengist-and peasants in rural Ethiopia: The post-2005 interlude. The Journal of Modern African Studies, 48(3), 435-460. doi:10. 1017/S0022278X10000297

Lessa, L. F., Belachew, M., \& Anteneh, S. (2011). Sustainability of E-Government project success: Cases from Ethiopia. Paper presented at the AMCIS, Detroit, MI.

Makki, F., \& Geisler, C. (2011). Development by dispossession: Land grabbing as new enclosures in contemporary Ethiopia. Paper presented at the International Conference on Global Land Grabbing, Sussex, UK.

Mammo, T. (1999). The paradox of Africa's poverty: The role of indigenous knowledge, traditional practices and local institutions. The case of Ethiopia. Lawrenceville, NJ: The Red Sea Press.

Mengisteab, K. (2008). Identity politics, democratisation and state building in Ethiopia's federal arrangement. African Journal on Conflict Resolution, 7(2), 63-92. doi:10.4314/ajcr.v7i2.39411

Meuleman, L. (2008). Public management and the metagovernance of hierarchies, networks and markets: The feasibility of designing and managing governance style combinations. Berlin: Springer Science \& Business Media.

Miller, P., \& Rose, N. (2008). Governing the present: Administering economic, social and personal life. Cambridge: Polity.

Painter, M., \& Pierre, J. (2005). Challenges to state pol- icy capacity: Global trends and comparative perspectives. New York: Palgrave Macmillan. doi:10.1057/ 9780230524194

Pausewang, S. (2004). The need for a third alternative: The amputated debate on land tenure in Ethiopia. Paper presented at the XI World Congress of Rural Sociology, Trondheim, Norway.

Peters, B. G., \& Pierre, J. (1998). Governance without government? Rethinking public administration. Journal of Public Administration: Research and Theory, 8(2), 223-243. doi:10.1093/oxfordjournals.jpart.a024379

Pierre, J., \& Peters, G. B. (2000). Governance, politics and the state. London: Palgrave Macmilan.

Rao, N., \& Berg, R. (2005). Transforming local political leadership. New York: Palgrave.

Saito, F. (2008). Foundations for local governance: Decentralization in comparative perspective. Heidelberg: Springer Science \& Business Media. doi:10. 1007/978-3-7908-2006-5

Schneider, A. (2003). Decentralization: Conceptualization and measurement. Studies in Comparative International Development, 38(3), 32-56. doi:10.1007/ BF02686198

Shah, A. (2006). Local governance in developing countries. Washington DC: World Bank Publications. doi: 10.1596/978-0-8213-6565-6

Snyder, K. A., Ludi, E., Cullen, B., Tucker, J., Zeleke, A. B., \& Duncan, A. (2014). Participation and performance: Decentralised planning and implementation in Ethiopia. Public Administration and Development, 34(2), 83-95. doi:10.1002/pad.1680

Stoker, G. (1998). Governance as theory: Five propositions. International Social Science Journal, 50(155), 17-28. doi:10.1111/1468-2451.00106

Treisman, D. (2007). The architecture of government: Rethinking political decentralization. Cambridge: Cambridge University Press. doi:10.1017/CBO9780 511619151

Turton, D. (2006). Ethnic federalism: The Ethiopian experience in comparative perspective. Oxford: James Currey.

Yilmaz, S., \& Venugopal, V. (2008). Local government discretion and accountability in Ethiopia (International Studies Program Working Paper, 8-38). Washington DC: World Bank.

Zewde, B., \& Pausewang, S. (Eds.). (2002). Ethiopia: The challenge of democracy from below. Uppsala and Addis Ababa: Nordic Africa Institute.

\section{About the Authors}

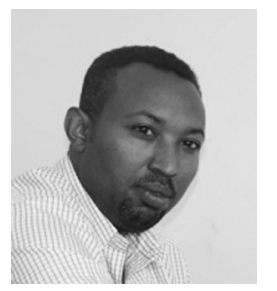

Yeshtila Wondemeneh Bekele is currently finalizing his PhD in Development Studies at the Norwegian University of Life Sciences. Yeshtila has substantial experience in research activities working as senior security and counter-terrorism analyst at the Ministry of Ethiopian National Defense and working as faculty member in different capacities at both Bahir Dar and Hawassa Universities. He serves at the Center for Policy and Development Research, Hawasa University, as Governance and Policy Cluster leader and senior researcher. He is also coordinating NORHED-DEG project funded by NORAD. 
Darley Jose Kjosavik is Associate Professor of International Development Studies at the Norwegian University of Life Sciences. She has a PhD in Development Studies from the same University. Her academic interests include political economy of development, decentralized governance, conflict and development, environment-development nexus, climate change adaptation and mitigation, gender and development and political economy of marginalization. Her latest book (co-authored with N. Shanmugaratnam) is titled Political Economy of Development in India: Indigeneity in Transition in the State of Kerala (Routledge London, 2015). 